\title{
Toxicity of the cyanobacterial cyclic heptapeptide toxins microcystin-LR and -RR in early life-stages of the African clawed frog (Xenopus laevis)
}

\author{
Werner J. Fischer, Daniel R. Dietrich * \\ Environmental Toxicology, University of Konstanz, Jacob-Burckhardtstr. 25, P.O. Box X918, D-78457 Konstanz, Germany
}

\begin{abstract}
Numerous cyanobacterial species are capable of producing potent toxins, which have been known to cause intoxications and fatalities in wildlife, livestock and humans. Microcystis is amongst the most ubiquitously distributed blue-green algal genus and almost invariably produces cyclic heptapeptide toxins called microcystins (MC). These toxins are highly persistent in water (several weeks). Highest concentrations are found in shallow littoral areas, the primary environment for aquatic early life-stage development. Therefore, the present study focussed on the potential embryotoxic effects of MC (MC-LR and -RR) in early life-stages of the amphibian Xenopus laevis. The endpoints chosen were mortality, malformation and growth inhibition. To achieve an improved dose-response relationship the uptake of MC was quantified simultaneously, using a radiolabeled derivative of MC-LR. As one of the best described molecular mechanisms of MC toxicity involves the specific inhibition of serine/threonine protein phosphatases-1 and $-2 \mathrm{~A}(\mathrm{PP})$, essential enzymes involved in the mechanisms of cell cycle regulation and maintenance of cellular morphology, the inhibition of PP in X. laevis exposed to MC was monitored. For this the presence of both PP-1 and PP-2A was confirmed by means of SDS-PAGE and immunoblotting. Second, the capacity of MC to inhibit $X$. laevis embryo-larval PP was corroborated by in vitro incubation of embryo-larval homogenates with MC-LR and -RR and subsequent determination of PP-inhibition. No increased mortality, malformation, or growth inhibition was observed even at the highest MC concentrations employed. MC had neither a demonstrable inhibitory effect on $X$. laevis PP-activity in vivo in the first $96 \mathrm{~h}$ of exposure. However, as of 96 and $120 \mathrm{~h}$ exposure a significant inhibition of PP activity was observed at the highest dose $(2000 \mu \mathrm{g} / 1)$ in MC-LR and MC-RR exposed embryo-larvae, respectively. By the same token, no notable amounts of radiolabeled $\left[{ }^{3} \mathrm{H}\right]-\mathrm{MC}-\mathrm{LR}$ were taken up during the first $96 \mathrm{~h}$, whereas a drastic increase in $\left[{ }^{3} \mathrm{H}\right]-\mathrm{MC}-\mathrm{LR}$ was observed after feeding of the larvae had commenced. The $\left[{ }^{3} \mathrm{H}\right]-\mathrm{MC}-\mathrm{LR}$ concentration was consistently found to be highest in the viscerothoracal sections of the larvae $(2112 \pm 429 \mu \mathrm{g} \mathrm{MC} / \mathrm{kg}$ dry weight after $120 \mathrm{~h}$ ). The present findings indicate that transchorional/transdermal absorption of $\mathrm{MC}$ in $X$. laevis is minimal or absent and that oral uptake of MC with ambient water is necessary for the development of MC related toxicity. Furthermore, the comparison of the MC doses used in this study with the concentrations reported in surface waters indicate that early life-stages of amphibians (up to 5 days of development) are unlikely to be affected by cyanobacterial blooms producing MC-LR and -RR.
\end{abstract}

Keywords: Xenopus laevis; Microcystin; Cyanobacteria; Uptake; Protein phosphatase-1 and -2A; Toxicity

* Corresponding author. Tel.: + 49-7531-88-3518, -4105; fax: + 49-7531-88-3170.

E-mail address: daniel.dietrich@uni-konstanz.de (D.R. Dietrich) 


\section{Introduction}

Fish kills have been widely reported in conjunction with cyanobacterial blooms, occurring in eutrophic and oligotrophic freshwater lakes, ponds, and other water bodies (Peñaloza et al., 1990; Toranzo et al., 1990; Andersen et al., 1993; Rodger et al., 1994; Mez et al., 1996; Watanabe et al., 1996; Devidze, 1998). Several cyanobacterial genera are capable of producing the bioactive secondary metabolites called microcystins (MC), the toxins which have been associated with the observed fish kills. Microcystins constitute a family of potent cyclic heptapeptide toxins that differ from one another mainly in two L-amino acid positions. Microcystin-LR with the structure cyclo (-D-Ala-LLeu-D-erythro- $\beta$-methyl-Asp-L-Arg-ADDA-DGlu- $N$-methyldehydro-Ala) has leucine and arginine at the variable sites (MW 995.2; Botes et al., 1982), and represents one of the best studied congeners of the microcystin family. Microcystins are retained within the cyanobacterial cells and released only upon lysis of the cells during the decomposition of cyanobacterial blooms (Watanabe et al., 1992). Microcystins were shown to be chemically very stable ( $\mathrm{pH}$, temperature, UV) in water, i.e. having a half-life of approximately 3 weeks at $\mathrm{pH} 1$ and $40^{\circ} \mathrm{C}$ (Harada, 1996). These laboratory data were corroborated by Jones and Orr (1994) who found measurable MC concentrations for up to 25 days following the decay of cyanobacterial blooms in surface waters.

The investigation of the mechanisms underlying cyanobacterial toxin induced fish kills by Tencalla et al. (1994) demonstrated that toxic cyanobacteria or toxin in the ambient water needed to be taken up orally in order to achieve sufficient systemic concentrations to exert the acute intoxication effects. On the other hand, Zambrano and Canelo (1996) reported that microcystin-LR can inhibit the ATPase activity of the $\mathrm{Na}^{+} \mathrm{K}^{+}$-pump in the gills of carp and thus suggested that disruption of ion-homeostasis in the gills could be the cause of massive fish deaths during cyanobacterial blooms. In either case, as well as reported in mammalian and avian species (Schwimmer and Schwimmer, 1968; Carmichael, 1997) the toxicity of MC is associated with the highly specific inhibi- tion $\left(\mathrm{IC}_{50} \approx 0.2 \mathrm{nM}\right)$ of serine/threonine phosphatases, namely protein phosphatases-1 and -2A (PP-1 and PP-2A) (MacKintosh et al., 1990). The inhibition of PP-1 and PP-2A would thus lead to the inhibition of the ATPase activity of the $\mathrm{Na}^{+}$ $\mathrm{K}^{+}$-pump in the gills of carp, as suggested by Zambrano and Canelo (1996), or to the dissociation of the hepatic cytoskeleton and subsequently to progredient liver necrosis and apoptosis, as shown by Tencalla and Dietrich (1997) and Fischer et al. (1999) in rainbow trout.

To date, no information is available as to the effects of MC in amphibians, specifically their early-life-stages. Indeed, the fact that amphibian early life-stages develop in the shallow littoral zone of surface waters in conjunction with the observation that cyanobacterial blooms frequently occur in the shallow littoral zone of a water body makes a co-occurrence of high microcystin concentrations and the early life-stage development of amphibians and fish highly likely. In addition, the observation that $\mathrm{MC}$ have a long half-life in surface waters, would suggest that amphibian eggs and embryo-larvae could be exposed to MC for a substantial time during their development. If indeed, ambient MC can interact directly with phosphatase dependent enzymes of the epithelial surface, e.g. ATPase activity of the $\mathrm{Na}^{+} \mathrm{K}^{+}$pumps, of aquatic organisms without having to be present systemically, an alteration of phosphatase dependent enzyme activities and thus developmental toxicity in early life-stages of amphibians would be likely.

In this study Xenopus laevis embryo-larvae were used to quantify the uptake of microcystin-LR and -RR. In order to determine the potential inhibitory effects of MC, the activity of PP-1 and $-2 \mathrm{~A}$ were determined simultaneously with the effects of MC exposure on early life-stage mortality and malformation.

\section{Materials and methods}

\subsection{Chemicals}

Microcystin-LR (MC-LR) and MC-RR were obtained from Calbiochem-Novabiochem 
(Germany). [ $\left.{ }^{32} \mathrm{P}\right]-\mathrm{ATP}$ was kindly provided by $\mathrm{Dr}$ W. Hofer (University Konstanz, Germany), $\left[{ }^{3} \mathrm{H}\right]-$ dihydro-MC-LR was a gift from Dr Jussi Meriluoto (Åbo Akademi University, Turku, Finland) and further synthesized in our laboratory. $\mathrm{NaB}^{3} \mathrm{H}_{4}$ was purchased from Amersham (TRK.45, Buckinghamshire, UK), BTS-450 tissue solubilizer and ReadySafe ${ }^{\mathrm{TM}}$ scintillation cocktail from Beckman (Beckman Instruments, USA). All other chemicals and solvents were of reagent grade and were obtained from Sigma (USA).

\subsection{Frog embryo-larvae and exposure scheme}

$X$. laevis embryo-larvae were bred from adult, wild caught South African animals (African Xenopus Facility, Noordhoek, South Africa). They were maintained in synthetic FETAX solution (ASTM, 1991) containing $625 \mathrm{mg} \mathrm{NaCl}, 96$ $\mathrm{mg} \mathrm{NaHCO}_{3}, 30 \mathrm{mg} \mathrm{KCl}, 15 \mathrm{mg} \mathrm{CaCl}_{2}, 60 \mathrm{mg}$ $\mathrm{CaSO}_{4} \times 2 \mathrm{H}_{2} \mathrm{O}$ and $75 \mathrm{mg} \mathrm{MgSO}_{4}$ per liter of reagent grade water in a 20-1 aquarium at $24 \pm$ $2^{\circ} \mathrm{C}$ under a 14-h/10-h light/dark cycle. Mating was induced by injection of gonadotropic hormones. A preboost of 250 and 150 IU of pregnant



Fig. 1. For determination of microcystin-LR and -RR toxicity to early life-stage $X$. laevis, embryos between stage 8 (midblastula) to 11 (early gastrula) were selected and used for experiments $(0 \mathrm{~h})$. Every $24 \mathrm{~h}$, a batch of animals was sacrificed for registration of death, malformations, growth inhibition, and inhibition of protein phosphatase-1 and -2A activity. (Modified from Nieuwkoop and Faber (1975)). mare's serum gonadotropin (PMSG, G-4877, Sigma, USA) was applied into the dorsal lymph sac of female and male frogs, respectively, followed by an injection of 700 and $600 \mathrm{IU}$ of human chorionic gonadotropin (HCG, GC-10, Sigma, USA) to female and male adults, respectively, $48 \mathrm{~h}$ after the first injection. The resulting fertilized eggs were collected, dechorionated for 2 $\min$ in $2 \%(\mathrm{w} / \mathrm{v})$ L-cystein solution $(\mathrm{pH} 8.1)$, sorted for viability and staged according to the criteria of Nieuwkoop and Faber (1975). Healthy looking embryos between stage 8 (midblastula) and 11 (early gastrula) were selected for experiments (Fig. 1).

\subsection{Toxicity of MC in early life-stages of Xenopus laevis}

Microcystin-LR and -RR testing solutions were prepared in FETAX solution at nominal concentrations of 2000, 500, 100, 10 and $1 \mu \mathrm{g} / 1$. Embryolarvae were exposed using a modified ASTM-stipulated FETAX procedure ( 25 embryos per replicate in $10 \mathrm{ml}$ testing media; ASTM, 1991). However, the exposure was static non-renewal and lasted 24, 48, 72, 96 and $120 \mathrm{~h}$, respectively. Testing temperature was held at $24 \pm 2{ }^{\circ} \mathrm{C}$ with a 14-h/10-h, light/dark cycle. Upon termination of exposure $X$. laevis larvae were washed with fresh FETAX solution and mortality, malformation and growth inhibition was recorded. One half of the animals were weighed and stored at $-80^{\circ} \mathrm{C}$ for subsequent extraction of protein phosphatases-1 and -2A (PP). For determination of PP-activity in whole larvae, whole larvae of the respective exposure groups were homogenized in four parts of ice cold PP-extraction buffer (consisting of: $50 \mathrm{mM}$ Tris/HCl; $4 \mathrm{mM}$ EDTA, $\mathrm{pH}$ 7; $250 \mathrm{mM}$ sucrose; $1 \mathrm{mM}$ phenylmethanesulfonyl fluoride (PMSF); $1 \mathrm{mM}$ benzamidine; 0.2\% (v/v) 2-mercaptoethanol; 2\% (v/v) Triton X$100^{\mathrm{TM}}$ ) with five strokes using a Potter-Elvehjemhomogenizer. Following centrifugation at $15000 \times g$ and $4^{\circ} \mathrm{C}$ for $10 \mathrm{~min}$, the remaining PP-activity in the supernatant was determined in the protein phosphatase activity assay (see below). 


\subsection{Western blot analysis}

The presence of protein phosphatases-1 and $-2 \mathrm{~A}$ in homogenates of various early life-stages of $X$. laevis was confirmed via Western blot analysis. $X$. laevis larvae were homogenized in $20 \mathrm{ml}$ ice cold extraction buffer (consisting of: $10 \mathrm{mM}$ Tris, $\mathrm{pH} 7.5 ; 140 \mathrm{mM} \mathrm{NaCl} ; 5 \mathrm{mM}$ EDTA; $1 \mathrm{mM}$ PMSF (phenylmethanesulfonyl fluoride); $1 \mathrm{mM}$ DTT; $1 \%$ Triton $\mathrm{X}-100^{\mathrm{TM}}$ ) per $\mathrm{g}$ tissue using six strokes at full speed and of a Potter-Elvehjem homogenizer. Course debris was centrifuged down for $10 \mathrm{~min}$ at $5000 \times g$ and $4^{\circ} \mathrm{C}$. The protein contents of the resulting $\mathrm{SN}$ were determined and the $\mathrm{SN}$ subsequently frozen at $-80^{\circ} \mathrm{C}$ until further analyzed. Proteins were separated using a $12 \%$ SDS-polyacrylamide gel electrophoresis system (SDS-PAGE) in a standard fashion. Following electrophoresis, proteins were blotted onto nitrocellulose membranes and probed with antihuman protein phosphatase-1 and -2A (Upstate biotechnology, USA), respectively. Antigen-primary antibody-complexes were detected with alkaline phosphatase-conjugated anti-rabbit antibodies and FastRed-chromogen (F-4648, Sigma, USA).

\subsection{Assay for the activity of ser/thr protein} phosphatases -1 and $-2 A$

$\left[{ }^{32} \mathrm{P}\right]$-Phosphorylase-a was prepared by the method of Cohen et al. (1988). The protein phosphatase inhibition assay was performed as described in the literature (Cohen et al., 1988) and briefly described below, including the molybdate extraction step described by MacKintosh (1993).

\subsection{Phosphorylation of phosphorylase- $b$ with} $\left[{ }^{32} P\right]-A T P$

A total of $0.08 \mathrm{ml}$ phosphorylase kinase (2 $\mathrm{mg} / \mathrm{ml}$ TEA buffer, consisting of: $50 \mathrm{mM}$ triethanolamine- $\mathrm{HCl}, \mathrm{pH} 7.0 ; 0.1 \mathrm{mM}$ EDTA; 15 $\mathrm{mM}$ caffeine; $0.1 \% \beta$-mercaptoethanol), $0.016 \mathrm{ml}$ $100 \mathrm{mM}$ Mg-acetate, $0.01 \mathrm{ml} 10 \mathrm{mM} \mathrm{CaCl}, 0.5$ $\mathrm{ml}$ phosphorylase-b (20 mg/ml TEA buffer), 2.5 $\mu \mathrm{l}$ cold $100 \mathrm{mM}$ ATP, $150 \mu 1125 \mathrm{mM}$ Tris $-\mathrm{HCl} /$ $125 \mathrm{mM}$ Na-glycerophosphate buffer, $\mathrm{pH} 8.6$ and
$100 \mu 1\left[{ }^{32} \mathrm{P}\right]$-ATP were incubated at $30^{\circ} \mathrm{C}$. After 60 min an equal volume of ice cold $90 \%$ saturated ammonium sulfate was added to stop the reaction and precipitate the protein. The reactants were left on ice for a further $30 \mathrm{~min}$. Following centrifugation in a microcentrifuge $(15000 \times g)$ for $10 \mathrm{~min}$, the supernatant was discarded and the pellet washed by resuspending in $1 \mathrm{ml} 45 \%$ saturated ammonium sulfate, centrifuged as described above and the supernatant discarded. The latter washing and centrifugation steps were repeated three times. After the last centrifugation step the residual ammonium sulfate was carefully removed with filter paper. Solubilization buffer $(856 \mu \mathrm{l} ; 50$ $\mathrm{mM}$ Tris-HCl, $\mathrm{pH}$ 7.0, $0.1 \mathrm{mM}$ EDTA, $15 \mathrm{mM}$ caffeine, $1 \%(\mathrm{v} / \mathrm{v}) \beta$-mercaptoethanol) was added to the remaining pellet which was carefully resuspended.

\subsection{Protein phosphatase assay}

In a preliminary assay, extracts of non-treated $X$. laevis larvae were taken through a time- and dilution series with protein phosphatase assay buffer (consisting of: $0.1 \mathrm{mM}$ EDTA; $20 \mathrm{mM}$ imidizole- $\mathrm{HCl}, \mathrm{pH} 7.63 ; 1 \mathrm{mg} / \mathrm{ml} \mathrm{BSA} ; 0.1 \%$ (v/v) $\beta$-mercaptoethanol) in order to find the linear range of dephosphorylation of the [ $\left.{ }^{32} \mathrm{P}\right]$-ATP-labeled substrate. In the final assay, $20 \mu$ of the respective $X$. laevis extracts from the individual microcystin exposures $(24-120 \mathrm{~h})$ were added to microreaction tubes containing $20 \mu \mathrm{l}$ of protein phosphatase assay buffer. The reaction was started by adding $20 \mu \mathrm{l}\left[{ }^{32} \mathrm{P}\right]$-phosphorylase-a to each assay tube. Following $10 \mathrm{~min}$ incubation at $30^{\circ} \mathrm{C}$ the reaction was stopped by addition of 180 $\mu \mathrm{l}$ ice cold $20 \%$ TCA and cooling on ice for at least $10 \mathrm{~min}$ after which the samples were microcentrifuged for $5 \mathrm{~min}$ at $15000 \times g$. Two hundred microliters of the respective supernatants were pipetted into separate tubes, $200 \mu \mathrm{l}$ of acid phosphate $\left(1.25 \mathrm{mM} \mathrm{KH}_{2} \mathrm{PO}_{4}\right.$ in $\left.0.5 \mathrm{M} \mathrm{H}_{2} \mathrm{SO}_{4}\right), 500 \mu \mathrm{l}$ isobutanol/heptane $(1: 2(\mathrm{v} / \mathrm{v}))$ as well as $100 \mu \mathrm{l}$ ammonium molybdate $(5 \%(\mathrm{w} / \mathrm{v}))$ added and then vigorously vortexed to extract $\left[{ }^{32} \mathrm{P}\right]$-orthophosphate. Three hundred microliters of the $\left[{ }^{32} \mathrm{P}\right]$-containing organic solvent layer was counted in a Beckman $\beta$-scintillation counter using Beckman 


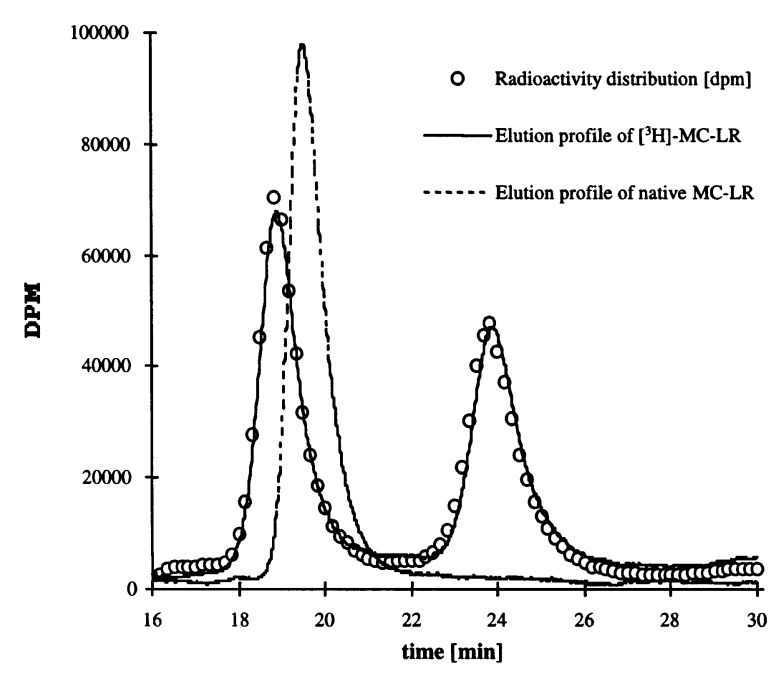

Fig. 2. HPLC-elution profiles of native microcystin (dotted line) and the two dihydro-microcystin epimers resulting from reductive labeling with $\mathrm{NaB}^{3} \mathrm{H}_{4}$ (solid line) prior to purification. The radioactivity distribution of $10 \mathrm{~s}$ fractions is shown as open circles. Isomer 1 appearing at a shorter retention time in the HPLC separation was used throughout the studies.

ReadySafe ${ }^{\mathrm{TM}}$ liquid scintillation cocktail (Beckman Instruments, USA).

\section{8. $\left[{ }^{3} H\right]$-labeling of microcystin-LR}

Synthesis of $\left[{ }^{3} \mathrm{H}\right]$-microcystin-LR by reduction of its $N$-methyldehydroalanine residue with $\left[{ }^{3} \mathrm{H}\right]-$ sodium borohydride was conducted after the method of Meriluoto et al. (1990). Briefly, $\mathrm{NaB}^{3} \mathrm{H}_{4}(1 \mathrm{mg})$ was dissolved in $1 \mathrm{ml}$ of 2propanol. Five hundred microliters of this mixture was diluted with $600 \mu$ of 2-propanol containing $1 \mathrm{mg}$ MC-LR and $500 \mu \mathrm{l}$ of distilled water. This mixture was left to react at room temperature for $22 \mathrm{~h}$ under continuous stirring. The labeling reaction was quenched with $10 \%$ acetic acid $(0.5 \mathrm{ml})$ and the reaction mixture subsequently evaporated to dryness at $40^{\circ} \mathrm{C}$ in a vacuum concentrator (Alpha-RVC, Christ, Germany).

The reaction products were then dissolved in 2 $\mathrm{ml} \mathrm{H}_{2} \mathrm{O}$ and applied on a preconditioned $\mathrm{C} 18$ solid phase extraction (SPE) cartridge (size 500 mg, IST, Germany). The cartridge was flushed with water $(3 \times 2 \mathrm{ml})$ and $3 \mathrm{ml}$ of $10 \%$ aqueous methanol. The flushing liquid was loaded onto another SPE cartridge that was then flushed in an identical manner as the first cartridge. The bound components were eluted with $100 \%$ methanol (5 $\mathrm{ml} /$ cartridge), the eluates combined and evaporated to dryness at $40^{\circ} \mathrm{C}$. Loosely incorporated tritium was removed by subsequent washing with $0.5 \mathrm{ml}$ trifluoroacetic acid. The solution was evaporated to dryness and the TFA wash and following drying procedure repeated for an additional four times.

The dry reaction products were dissolved in HPLC mobile phase. Final purification was accomplished by high-performance liquid chromatography (HPLC) using a reversed-phase semipreparative column (Grom-Sil 120 ODS-4 HE, $11 \mu \mathrm{m}, 250 \times 8 \mathrm{~mm}$, Grom, Germany). The mobile phase, running at $3 \mathrm{ml} / \mathrm{min}$, consisted of $27 \%$ acetonitrile and $73 \% 0.0135 \mathrm{M}$ aqueous ammonium acetate. Two radioactive peaks appeared, one slightly before and another after the retention time of native microcystin-LR and were collected separately (Fig. 2). After a further drying of the collected fractions followed by SPE as described above, the chemical and radiochemical purities of the labels were determined by HPLC (Grom-Sil 120 ODS $-4 \mathrm{HE}, 11 \mu \mathrm{m}, 250 \times 8 \mathrm{~mm}$, Grom, Germany) using a methanol/water (60/40) mobile phase and $\beta$-scintillation spectrometry, respectively.

Two stereoisomers resulted from the reductive labeling reaction of microcystin-LR with $\mathrm{NaB}^{3} \mathrm{H}_{4}$. Only isomer 1 appearing at a shorter retention time in the HPLC separation (Fig. 2) was used for uptake studies, since it is reported to be taken up into target cells at a higher rate than isomer 2 (Meriluoto et al., 1990). Isomer 1 ([$\left.\left.{ }^{3} \mathrm{H}\right]-\mathrm{MCLR}\right)$ was purified to a chemical purity of $99.4 \%$ and a radiochemical purity of $99.7 \%$. The specific activity was $18.7 \mathrm{GBq} / \mathrm{mmol}$.

\subsection{Uptake of $\left[{ }^{3} H\right]$-dihydro-MC-LR in $X$. laevis}

For the preparation of testing media $\left[{ }^{3} \mathrm{H}\right]$-dihydro-MC-LR was diluted in FETAX solution to a concentrations of $450 \mu \mathrm{g} / \mathrm{l}$. Embryos $(5 \times 20)$ were 


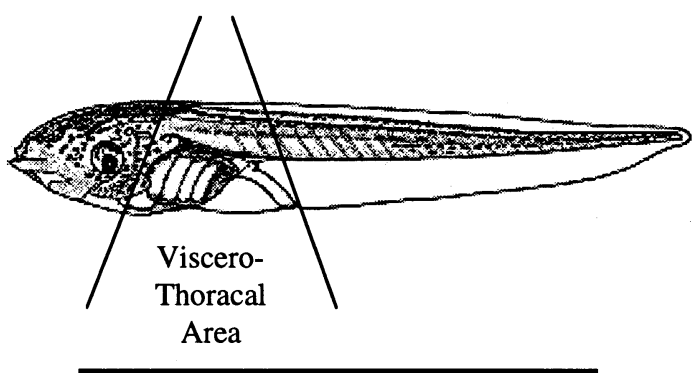

$10 \mathrm{~mm}$

Fig. 3. X. laevis larva $120 \mathrm{~h}$ old. For the uptake of $\left[{ }^{3} \mathrm{H}\right]$-dihydro-microcystin-LR and a better localization of the radiolabel, larvae, after 24, 48, 72, 96 and $120 \mathrm{~h}$ were either used whole or dissected along the indicated lines into cranial, caudal and viscerothoracal sections, prior to homogenization and determination of radioactivity.

exposed 24, 48, 72, 96 and $120 \mathrm{~h}$ in 6-cm glass petridishes containing $10 \mathrm{ml}$ test solution. The exposure was static without media renewal at $24 \pm 2{ }^{\circ} \mathrm{C}$ with a $14-\mathrm{h} / 10$-h, light/dark cycle. Upon termination of the exposure, larvae were collected,



Fig. 4. Immunoblotting of larval $X$. laevis homogenates. (A) Seventy-two hour-old control-larva-homogenate $(2.5 \mu \mathrm{g}$ protein/lane) probed with anti-human protein phosphatase-1 antibody $(2 \mu \mathrm{g} / \mathrm{ml})$ and detected with anti-rabbit IgG-AP and Fast Red. (B) One hundred and twenty hour-old control-larvahomogenate $(2 \mu \mathrm{g}$ protein/lane) probed with anti-human protein phosphatase-2A antibody $(2 \mu \mathrm{g} / \mathrm{ml})$ and detected with anti-rabbit IgG-AP and Fast Red. thoroughly washed with fresh FETAX solution, either used whole or dissected into cranial, caudal and viscerothoracal sections (Fig. 3) and digested in $0.5 \mathrm{ml}$ BTS-450 tissue solubilizer in a glass scintillation vial at $40^{\circ} \mathrm{C}$ overnight. Following addition of ReadySafe ${ }^{\mathrm{TM}}$ scintillation cocktail, the samples were submitted to liquid scintillation spectrometry.

\subsection{Statistics}

Comparison of PP-activities: $t$-test or MannWhitney $U$-test was used to determine whether FETAX-controls and solvent controls could be pooled. Kruskal-Wallis one-way analysis by ranks or one-way ANOVA followed by a 'one-tomany Tukey post hoc test' were used to identify concentrations, which were significantly different from controls.

\section{Results}

\subsection{Toxicity of $M C-L R$ and $-R R$ to early life-stages of $X$. laevis}

No apparent increase in mortality, malformation or growth inhibition could be observed in $X$. laevis embryo-larvae and larvae (developmental stages 9-46 (Nieuwkoop and Faber, 1975)) exposed for up to 5 days to microcystin-LR and -RR at concentrations ranging from 1 to 2000 $\mu \mathrm{g} / 1$ (data not shown).

\subsection{Protein phosphatases -1 and $-2 A$ activity in $X$. laevis}

PP-1 \& PP-2A were shown to be present in early life-stages of $X$. laevis (Fig. 4) and inhibitable by MC-LR and -RR in vitro (Fig. 5). No in vivo inhibition of $X$. laevis PP-1 and -2A enzyme activity was detectable until $96 \mathrm{~h}$ of exposure for MC-RR and -LR (Fig. 6) in the whole embryo-larval extracts. However, significant differences in PP activity were observed for the highest dose $(2000 \mu \mathrm{g} / \mathrm{l})$ as of 96 and $120 \mathrm{~h}$ of larval development (Fig. 6). 


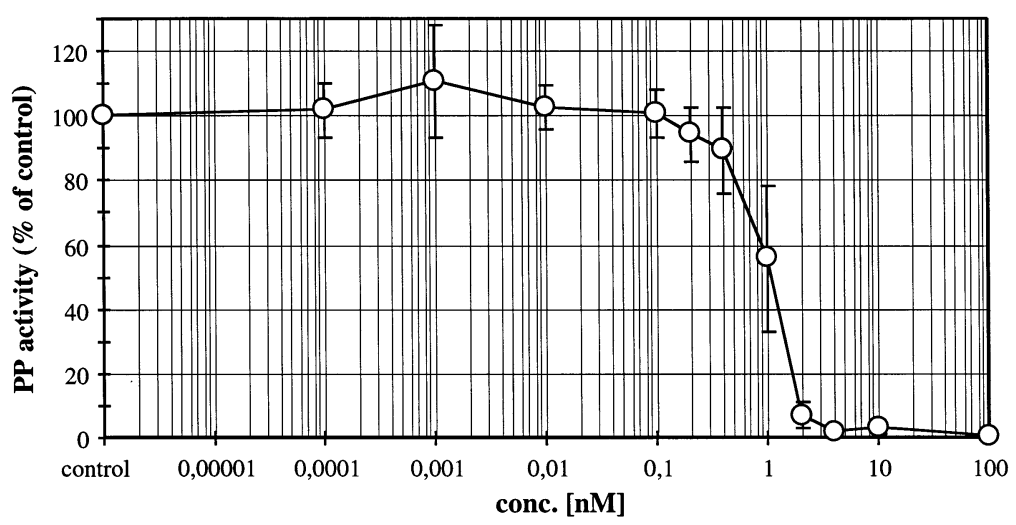

Fig. 5. In vitro inhibition of protein phosphatases (PP)-1 and -2A of early life-stages of $X$. laevis. $X$. laevis homogenates ( $n=3$ ) were incubated with microcystin-RR at the indicated concentrations. Subsequently the PP-activity was measured in the PP-assay. Microcystin-LR (data not shown gave similar inhibition values).

\subsection{Uptake of $\left[{ }^{3} \mathrm{H}\right]$-dihydro-MC-LR in early} life-stages of $X$. laevis

Radioactive MC-LR was barely detectable in embryo-larvae younger than $96 \mathrm{~h}$ of development (Fig. 7). In contrast, a dramatic increase of $\left[{ }^{3} \mathrm{H}\right]-$ MC-LR could be detected in larvae of age $96 \mathrm{~h}$ and older. The highest amount of radioactivity was consistently found in the viscerothoracal part of the body, corresponding to $1391 \pm 445 \mu \mathrm{g} \mathrm{MC} /$ $\mathrm{kg}$ dry weight after $96 \mathrm{~h}$ and $2112 \pm 429 \mu \mathrm{g} \mathrm{MC} /$ kg dry weight after 120 h (Fig. 7). Radioactivity found in whole bodies of $X$. laevis larvae was consistently lower (corresponding to $871 \pm 96 \mu \mathrm{g}$ $\mathrm{MC} / \mathrm{kg}$ dry weight after $96 \mathrm{~h}$ and $1011 \pm 230 \mu \mathrm{g}$ $\mathrm{MC} / \mathrm{kg}$ dry weight after $120 \mathrm{~h}$ ) than in the viscerothoracal section while virtually no radioactivity was present in both the cranial and caudal sections (Fig. 7).

\section{Discussion and conclusion}

During the entire exposure period (max. $120 \mathrm{~h}$ ) to microcystin-LR and -RR (MC), no increased mortality, malformation or growth inhibition could be detected in early life-stages of $X$. laevis. In agreement with the latter observation, embryolarval protein phosphatase- 1 and -2A activity did not seem to be significantly inhibited during the first $96 \mathrm{~h}$ of exposure and irrespective of the $\mathrm{MC}$

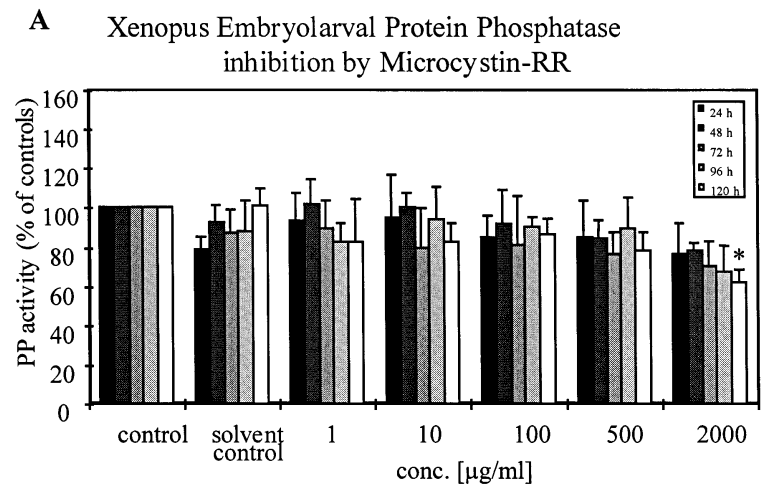

B Xenopus Embryolarval Protein Phosphatase Inhibition by Microcystin-LR

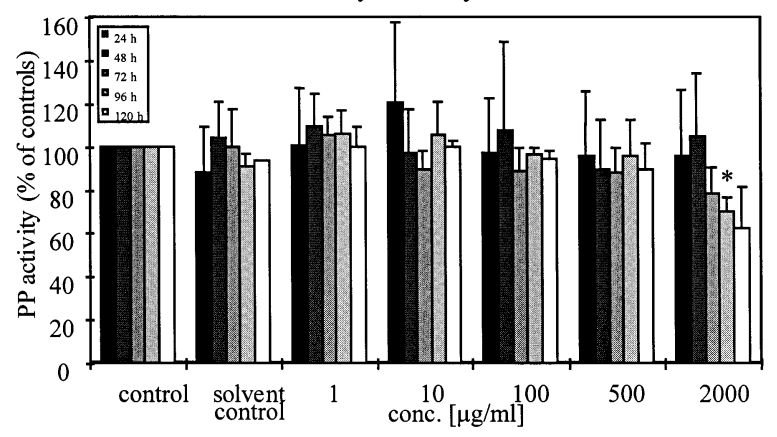

Fig. 6. X. laevis embryo-larval protein phosphatase activity $(n=3)$ after in vivo exposure to microcystin-RR $(6 \mathrm{~A})$ and microcystin-LR (6B). Significant difference to control, $* P<$ $0.05,1-\beta_{\mathrm{MC}-\mathrm{LR}}=0.802,1-\beta_{\mathrm{MC}-\mathrm{RR}}=0.825$ 

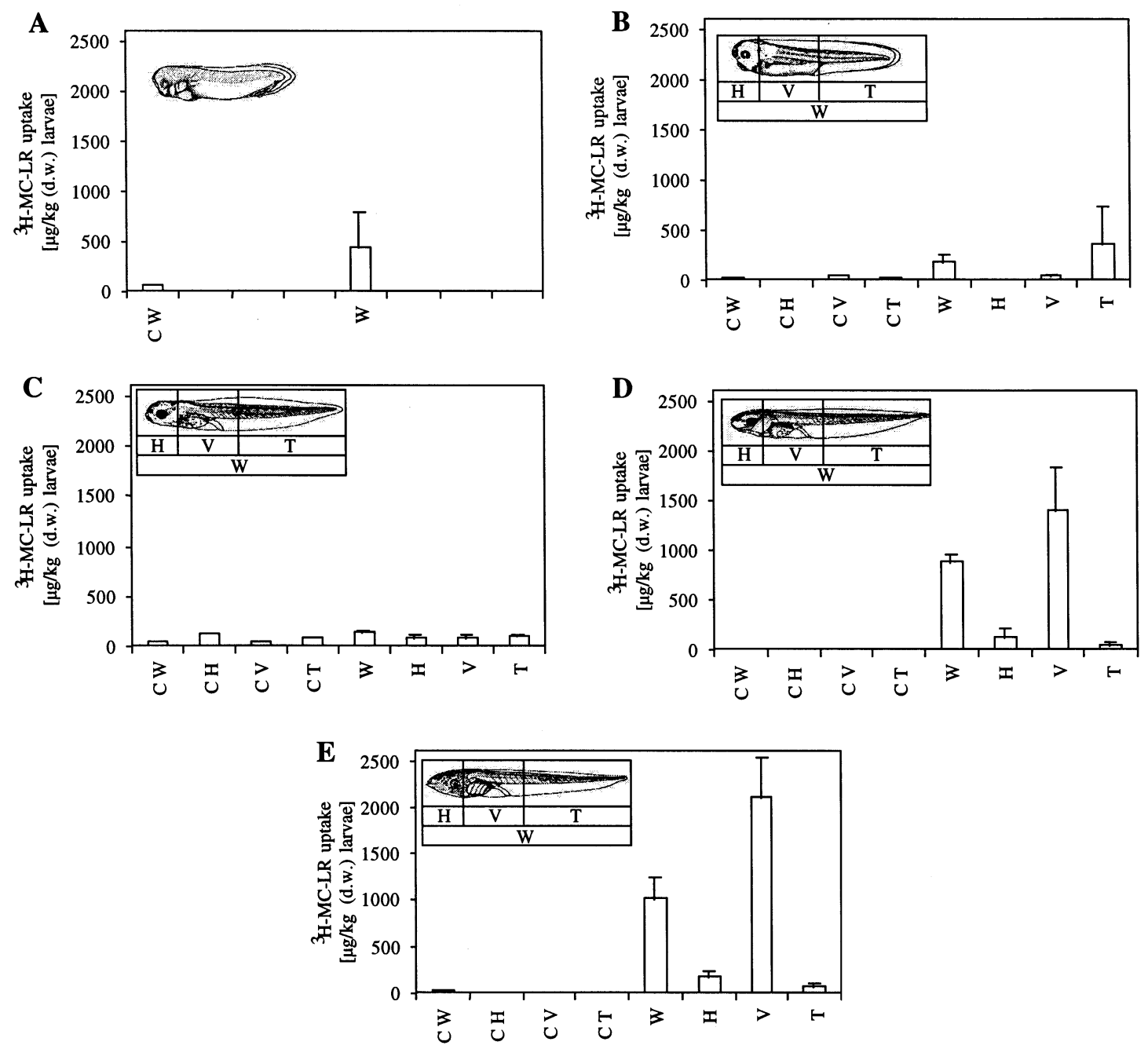

Fig. 7. $\left[{ }^{3} \mathrm{H}\right]-\mathrm{MC}-\mathrm{LR}$ uptake by different larval life-stages of $X$. laevis $(n=3)$ at an exposure concentration of $450 \mu \mathrm{g} / \mathrm{l}(\mathrm{A}, 24 \mathrm{~h}$ of age; B, 48 h; C, 72 h; D, 96 h; E, 120 h). Data is shown for different body parts of the larvae: H, cranial section; T, caudal section; $\mathrm{V}$, viscero-thoracal section; W, whole animal. C, control; d.w., dry weight.

concentrations used. The apparent absence of PP inhibition cannot be attributed to an inherent insensitivity of $X$. laevis $\mathrm{PP}$ to $\mathrm{MC}$, since its activity could be hampered in vitro by purified MC-LR and -RR in a dose dependent fashion (Fig. 5). $\mathrm{IC}_{50} \mathrm{~s}$ of the combined enzymes were obtained at $\approx 1 \mathrm{nM}$ for both MC-LR and MC$\mathrm{RR}$, which is in agreement with the data reported in the literature for mammalian, fish and plant species (MacKintosh et al., 1990; Tencalla and Dietrich, 1997). Indeed, PP inhibition was ob- served as of $96 \mathrm{~h}$ exposure at the highest MC concentrations employed and therefore also suggests that, in conjunction with the fact that $X$. laevis larvae commence feeding as of day 4 following egg fertilization (Nieuwkoop and Faber, 1975), MC was taken up orally. Indeed the latter suggestion is supported by the observation that as of $96 \mathrm{~h}$ of exposure a dramatic increase in radioactive $\mathrm{MC}$ can be detected in $X$. laevis larvae (Fig. 7). In contrast to the hypothesis by Zambrano and Canelo (1996), the present data thus 
indicate that $\mathrm{MC}$ cannot be taken up transchorionally/transdermally nor exhibits any topical toxic effects in $X$. laevis embryo-larvae/larvae, but needs to be taken up orally to exert any toxic effects.

The observed PP inhibition (Fig. 6) at 96 and $120 \mathrm{~h}$, however, appeared to be insufficient to induce mortality or measurable malformation and growth inhibition. This could mean that even after $96 \mathrm{~h}$ insufficient amounts of microcystin were taken up orally for marked inhibition of the PP present. However, when comparing the PP inhibition data with the data from the $\left[{ }^{3} \mathrm{H}\right]-\mathrm{MC}$ LR experiments, the calculated dose of MC taken up amounted to $\approx 50 \mu \mathrm{g} / \mathrm{kg}$ wet weight indicating that much higher doses were taken up than as suggested by the PP inhibition assay. This calculated dose is comparable to those i.p. doses reported to induce $50 \%$ mortality in mice and rats (Rinehart et al., 1994) and cause acute toxic effects in fish (carp) (Carbis et al., 1996) and thus should have lead to a greater inhibition of the $X$. laevis PP present. The determination of PP inhibition in whole embryo-larvae and larvae may have been too insensitive due to the large amounts of PP present from non-target tissues for MC toxicity. Indeed, MC were shown to be highly organotropic for the liver, the route of uptake believed to be principally via the gastrointestinal tract and portal vein into the liver (Dahlem et al., 1989; Bury et al., 1998) where they are assumed to be taken up specifically via bile acid carriers into the hepatocytes (Eriksson et al., 1990; Runnegar et al., 1991, 1995). This high organotropy for the liver is at least partially corroborated by the findings presented in this study demonstrating that most of the MC related radioactivity was also present in the viscerothoracal section. Had liver specific determinations of PP inhibition been possible, these could have demonstrated a degree of PP inhibition more consistent with MC exposure concentrations and the amounts of MC taken up. However, a more sensitive detection of liver specific PP inhibition still cannot explain the observed lack of overt toxicity in the $X$. laevis larvae. An explanation of this phenomenon, although at present mere speculation, could be that early lifestages of $X$. laevis are not susceptible to $\mathrm{MC}$ toxicity until a functional liver with organic anion carriers has developed. Indeed, the first indications of the presence of a liver in $X$. laevis is reported to be as of day 3 post-fertilization (Deuchar, 1966; Nieuwkoop and Faber, 1975). The question therefore remains to be answered whether this embryo-larval liver can become fully functional and thus susceptible for specific MC uptake and toxicity within the following 2 days (days 4 and 5) of development.

In conclusion, the present findings indicate that transchorional/transdermal absorption of $\mathrm{MC}$ in $X$. laevis is minimal or absent and that oral uptake of MC with ambient water is necessary for the development of MC related toxicity. Furthermore, the comparison of the doses used in these experiments with the concentrations of MC reported to be present in the littoral of freshwaters (Watanabe et al., 1996) indicate that early lifestages (up to 5 days of development) of amphibians are unlikely to be affected by cyanobacterial blooms producing microcystin-LR and -RR.

\section{Acknowledgements}

We thank Professor Dr W. Hofer (University Konstanz) for his generous expertise with the PP-assay and kindly providing $\left[{ }^{32} \mathrm{P}\right]$-ATP. We are grateful for advice and receiving $\left[{ }^{3} \mathrm{H}\right]$-MCLR from Dr Jussi Meriluoto (Åbo Akademi University, Turku, Finland). This study was funded by the European Union: INCO-Copernicus, ProjectNr. ERBIC15CT961010.

\section{References}

Andersen, R.J., Luu, H.A., Chen, D.Z.X., Holmes, C.F.B., Kent, M.L., Le Blanc, M., Taylor, F.J.R., Williams, D.E., 1993. Chemical and biological evidence links microcystins to salmon 'netpen liver disease'. Toxicon 31, 1315-1323.

ASTM, 1991. Standard guide for conducting the Frog Embryo Teratogenesis Assay-Xenopus (Fetax). E 1439-91. In: Storer, R.A. (Ed.), Annual Book of ASTM Standards. American Society for Testing and Materials, Philadelphia, PA, pp. 1-11.

Botes, D.P., Kruger, H., Viljoen, C.C., 1982. Isolation and characterization of four toxins from the blue-green alga Microcystis aeruginosa. Toxicon 20, 945-954. 
Bury, N., Newlands, A., Eddy, F., Codd, G., 1998. In vivo and in vitro intestinal transport of ${ }^{3} \mathrm{H}$-microcystin-LR, a cyanobacterial toxin, in rainbow trout (Oncorhynchus mykiss). Aquat. Toxicol. 42, 139-148.

Carbis, C., Rawlin, G., Mitchell, G., Anderson, J., McCauley, I., 1996. The histopathology of carp, Cyprinus carpio L., exposed to microcystin by gavage, immersion and intraperitoneal administration. J. Fish Dis. 19, 199-207.

Carmichael, W.W., 1997. The cyanotoxins. In: Advances in Botanical Research. pp. 211-256.

Cohen, P., Alemany, S., Hemmings, B.A., Resink, T.J., Stralfors, P., Tung, H.Y.L., 1988. Protein phosphatase-1 and protein phosphatase-2A from rabbit skeletal muscle. Methods Enzymol. 159, 390-408.

Dahlem, A.M., Hassan, A.S., Swanson, S.P., Carmichael, W.W., Beasley, V.R., 1989. A model system for studying the bioavailability of intestinally administered microcystinLR, a hepatotoxic peptide from the cyanobacterium $\mathrm{Mi}$ crocystis aeruginosa. Pharmacol. Toxicol. 64, 177-181.

Deuchar, E.M., 1966. Biochemical Aspects of Amphibian Development. Methuen, London, p. 206.

Devidze, M., 1998. Harmful algal events in Georgian waters. In: Reguera, B., Blanco, J., Fernández, L., Wyatt, T. (Eds.), Harmful Algae. Xunta de Galicia and Intergovernmental Oceanographic Commission of UNESCO, pp. 91.

Eriksson, J.E., Grönberg, L., Nygård, S., Slotte, J.P., Meriluoto, J.A.O., 1990. Hepatocellular uptake of ${ }^{3}$ H-dihydromicrocystin-LR, a cyclic peptide toxin. Biochim. Biophys. Acta 1025, 60-66.

Fischer, W.F., Hitzfeld, B.C., Eriksson, J.E., Mikhailov, A., Dietrich, D.R., 1999. Microcystin-LR toxicodynamics, induced pathology and immunohistochemical detection in livers of rainbow trout. Toxicol. Sci. 48, 33.

Harada, K., 1996. Chemistry and detection of microcystins. In: Watanabe, M., Harada, K., Carmichael, W., Fujiki, H. (Eds.), Toxic Microcystis. CRC Press, Boca Raton, FL, pp. 103-148.

Jones, G.J., Orr, P.T., 1994. Release and degradation of microcystin following algicide treatment of a Microcystis aeruginosa bloom in a recreational lake, as determined by HPLC and protein phosphatase inhibition assay. Water Res. 28, 871-876.

MacKintosh, C., 1993. Assay and purification of protein (serine/threonine) phosphatases. In: Hardie, D.G. (Ed.), Protein Phosphorylation: A Practical Approach. Oxford University Press, Oxford, pp. 197-229.

MacKintosh, C., Beattie, K.A., Klumpp, S., Cohen, P., Codd, G.A., 1990. Cyanobacterial microcystin-LR is a potent and specific inhibitor of protein phosphatases 1 and $2 \mathrm{~A}$ from both mammals and higher plants. FEBS Lett. 264, 187192.

Meriluoto, J.A.O., Nygård, S., Dahlem, A.M., Eriksson, J.E., 1990. Synthesis, organotropism and hepatocellular uptake of two tritium-labeled epimers of dihydromicrocystin-LR, a cyanobacterial peptide toxin analog. Toxicon 28, 14391446.

Mez, K., Hanselmann, K., Naegeli, H., Preisig, H., 1996. Protein phosphatase-inhibiting activity in cyanobacteria from alpine lakes in Switzerland. Phycologia 36, 133-139.

Nieuwkoop, P.D., Faber, J., 1975. Normal Table of Xenopus Laevis (Daudin): A Systematical and Chronological Survey of the Developmental Stages from the Fertilized Egg Till the End of Metamorphosis. North-Holland, Amsterdam, p. 252.

Peñaloza, R., Rojas, M., Vila, I., Zambrano, F., 1990. Toxicity of a soluble peptide from Microcystis sp. to zooplankton and fish. Freshwater Biol. 24, 233-240.

Rinehart, K.L., Namikoshi, M., Choi, B.W., 1994. Stucture and biosynthesis of toxins from blue-green algae (cyanobacteria). J. Appl. Phycol. 6, 159-176.

Rodger, H.D., Turnbull, T., Edwards, C., Codd, G.A., 1994. Cyanobacterial (blue-green-algal) bloom associated pathology in brown trout, Salmo trutta L., in Loch Leven, Scotland. J. Fish Dis. 17, 177-181.

Runnegar, M., Berndt, N., Kaplowitz, N., 1995. Microcystin uptake and inhibition of protein phosphatases: effects of chemoprotectants and self-inhibition in relation to known hepatic transporters. Toxicol. Appl. Pharmacol. 134, 264272.

Runnegar, M.T.C., Gerdes, R.G., Falconer, I.R., 1991. The uptake of the cyanobacterial hepatotoxin microcystin by isolated rat hepatocytes. Toxicon 29, 43-51.

Schwimmer, M., Schwimmer, D., 1968. Medical aspects of psychology. In: Jackson, D.F. (Ed.), Algae, Man, and the Environment. Syracuse University Press, Syracuse, NY, pp. 279-358.

Tencalla, F., Dietrich, D., 1997. Biochemical characterization of microcystin toxicity in trout (Oncorhynchus mykiss). Toxicon 35, 583-595.

Tencalla, F.G., Dietrich, D.R., Schlatter, C., 1994. Toxicity of Microcystis aeruginosa peptide toxin to yearling rainbow trout (Oncorhynchus mykiss). Aquat. Toxicol. 30, 215-224.

Toranzo, A.E., Nieto, F., Barja, J.L., 1990. Mortality associated with cyanobacterial bloom in farmed rainbow trout in Galicia (Northwestern, Spain). Bull. Eur. Ass. Fish Pathol. 10, 106-107.

Watanabe, M.F., Harada, K.-I., Carmichael, W.W., Fujiki, H., 1996. Toxic Microcystis. CRC Press, Boca Raton, FL, p. 262.

Watanabe, M.F., Tsuji, K., Watanabe, Y., Harada, K.-I., Suzuki, M., 1992. Release of heptapeptide toxin (microcystin) during the decomposition process of Microcystis aeruginosa. Nat. Toxins 1, 48-53.

Zambrano, F., Canelo, E., 1996. Effects of microcystin-LR on the partial reactions of the $\mathrm{Na}+-\mathrm{K}+$ pump of the gill of carp (Cyprinus carpio Linneo). Toxicon 34, 451-458. 